\title{
Body mass variation in the Geoffroy's cat (Oncifelis geoffroyi)
}

\author{
Variaciones de la masa corporal del gato montés (Oncifelis geoffroyi)
}

\author{
MAURO LUCHERINI ${ }^{1,2^{*}}$, CLAUDIA MANFREDI ${ }^{1,3}$, ESTELA LUENGOS ${ }^{1,3}$, FÁBIO DIAS MAZIM $^{4}$, LUCÍA SOLER
} \& EMMA B. CASANAVE ${ }^{1,2 *}$

\author{
${ }^{1}$ Grupo de Ecología Comportamental de Mamíferos (GECM), Cátedra de Fisiología Animal, Departamento de Biología, \\ Bioquímica y Farmacia, Universidad Nacional del Sur, San Juan 670, (8000) Bahía Blanca, Argentina \\ ${ }^{2}$ Consejo Nacional de Investigaciones Científicas y Técnicas (CONICET) Researcher \\ ${ }^{3}$ Consejo Nacional de Investigaciones Científicas y Técnicas (CONICET) Scholarship \\ ${ }^{4}$ South American Cats Conservation Alliance (SACCA), Rua Padre Anchieta, 1277, 201, \\ Centro, Pelotas - RS, 46015-420, Brazil; \\ * e-mail for correspondence: luengos@criba.edu.ar
}

\begin{abstract}
We report new data on the intersexual and geographical variation in body mass of the Geoffroy's cat (Oncifelis geoffroyi d'Orbigny and Gervais 1844), a little known small cat from South America, and combine them with the existing information to compare alternative hypotheses for variation in body mass. Most data on the body mass of $O$. geoffroy $i$ have been obtained from previous research on this felid in four study areas of southern Brazil and central and southern Argentina. These data were added to those reported for other three additional locations. Our results set the body mass of $O$. geoffroyi to $4.26 \pm 1.03 \mathrm{~kg}$ (mean $\pm \mathrm{SD}, \mathrm{n}=56$ ). We also show that males generally are heavier than females throughout most of this species' distributional range. Body mass dimorphism is 1.34 on average, but ranges from 1.19 and 1.21 in Uruguay and southern Chile, respectively, to 1.76 in the northern Pampas of Argentina. When data from the best sampled areas are considered (Torres del Paine, Lihué Calel, southern Pampas, Campos del Tuyú and southern Brazil), only male body mass varies with geographic location. More intriguingly, no correlation was found between body mass and latitude. Our results suggest a smaller mean weight of $O$. geoffroyi relative to what was previously published, but also suggest a wider variation. Our analysis do not support Bergmann's rule, according to which the largest individuals would occur in the southernmost regions of this cat's geographic distribution, while they seem supportive of a sexually-selected process affecting sexual size dimorphism in the Geoffroy's cat.
\end{abstract}

Key words: carnivores, felids, Oncifelis geoffroyi, South America, body mass.

\section{RESUMEN}

Se reportan nuevos datos sobre la variación intersexual y geográfica de la masa corporal en el gato montés (Oncifelis geoffroyi d'Orbigny and Gervais 1844), un félido pequeño y poco conocido de América del Sur, y los combinamos con la información existente para evaluar dos hipótesis que explicarían esta variación. La mayor parte de los datos sobre masa corporal de O. geoffroyi fueron obtenidos en el marco de proyectos de investigación sobre este félido en cuatro áreas del sur de Brasil y centro y sur de Argentina. Estos datos se agregaron con registros para otras tres localidades. Nuestros resultados establecieron que la masa corporal promedio de $O$. geoffroyi fue de 4,26 kg ( $\mathrm{DE}=1,03 \mathrm{~kg} ; \mathrm{n}=56)$. Demostramos además que los machos son más grandes que las hembras, y que este dimorfismo sexual ocurre en la mayoría de las localidades muestreadas a lo largo del rango de distribución de esta especie. El dimorfismo sexual en la masa corporal fue de 1,34 en promedio, pero varió entre 1,19 y 1,21 en Uruguay y Chile meridional, respectivamente, hasta 1,76 en la Pampa septentrional argentina. Al comparar los datos de las cinco localidades con mayor número de registros (Torres del Paine, Lihué Calel, Pampas meridionales, Campos del Tuyú y Brasil meridional) se encontró variación geográfica significativa solo en la masa corporal de los machos. No se registró una correlación positiva entre la masa corporal y la latitud. Estos resultados sugieren que el tamaño promedio de $O$. geoffroyi es menor que lo sugerido por registros anteriores, pero también sugieren que su variabilidad es mayor. Nuestro análisis no apoya la regla de Bergmann en cuanto a que los individuos más grandes se encontrarían en las regiones más meridionales de la distribución geográfica, mientras que sí apoyan un escenario de selección sexual para el dimorfismo sexual en el tamaño observado en este felino.

Palabras clave: carnívoros, félidos, Oncifelis geoffroyi, América del Sur, masa corporal. 


\section{INTRODUCTION}

Carnivores often have large distributions and different populations of the same species are frequently found under very different climatic conditions or different suites of potential prey and competitors. These different populations are subject to different selective pressures, which are probably reflected in variations in many traits, especially body size and sexual dimorphism (Van Valkenburgh \& Wayne 1994, Gittleman 1995, Dayan \& Simberloff 1996). It has been shown that body size is directly correlated with latitude in most mammals (Ashton et al. 2000) and, in particular, some carnivores (Rosenzweig 1968, Davis 1981, Klein 1986). The so-called Bergmann's rule (following Mayr's 1956 formulation) states that individuals increase their size toward higher latitudes to cope with stressfully low temperatures. In many cases, however, deviations from Bergmann's rule have been found (e.g., Erlinge 1987, Dayan et al. 1989a, 1989b) and alternative hypotheses have been proposed (e.g., McNab 1971, Powell \& King 1997).

On the other hand, niche separation and sexual selection have been invoked to explain sexual dimorphism in carnivore body size (Ralls 1976). Under a niche segregation scenario, dimorphism allows males and females to reduce inter-sexual competition over food resources through exploiting different prey sizes. From this point of view, the two sexes of the same species would behave as different species in order to reduce niche overlap and, consequently, inter-sexual competition over food (Hedrick \& Temeles 1989, Dayan \& Simberloff 1996). Under the niche separation hypotheses, either males or females are expected to become bigger because no sexrelated pressure is acting. The second explanation attributes sexual differences to separate selective pressures (maximize reproductive success in females and female access in males). In this case, males are expected to increase their body size to compete with other such males over the access to females (Erlinge 1979, Moors 1980). Thom et al. (2004) suggested that, at least in carnivores, niche separation is probably not the driving force behind sexual dimorphism but can help maintaining it.
Due to its wide range of occurrence and relatively small size (which makes animals more susceptible to temperature variations), the Geoffroy's cat (Oncifelis geoffroyi d'Orbigny and Gervais 1844) is especially appropriate for a test of Bergmann's rule. This carnivore lives from southern Bolivia and the Parana basin of southern Brazil to the southern tip of Patagonia in Chile and Argentina (Cabrera 1957, Ximénez 1975 , Sunquist \& Sunquist 2002), i.e., from $13^{\circ}$ to almost $53^{\circ}$ of latitude south. It occurs in savannas, woodlands and scrublands up to 3,300 m of altitude (e.g., Olrog \& Lucero 1981, Redford \& Eisenberg 1992). However, in spite of its wide distribution and Near Threatened conservation status (Nowell 2002a), very little information is available on this cat (Nowell \& Jackson 1996, Nowell 2002b, Lucherini et al. 2004).

Here we report new data on the inter-sexual and geographical variation in body mass of the Geoffroy's cat and combine them with the existing information to contrast alternative hypotheses explaining body mass variation. In the case of body mass, we test the main prediction of Bergmann's rule where body mass of $O$. geoffroyi increases with latitude. Secondly, we examine the occurrence of sexual size dimorphism and use the available information on the ecology of this cat to discuss the influence of sexual selection in explaining such variability.

\section{MATERIAL AND METHODS}

Most data on the body mass of adult $O$. geoffroyi (Table 1) were obtained from individuals restrained as a part of research on the conservation biology of this felid in Argentina. We sexed and weighed (with a Pesola $($ ) scale, $250 \mathrm{~g}$ of precision) six individuals (three males and three females) in the E. Tornquist Provincial Park $\left(38^{\circ} \mathrm{S}, 63^{\circ} \mathrm{W}\right.$, southern Buenos Aires province), five (three females and two males) in Campos del Tuyú Wildlife Reserve of the Fundación Vida Silvestre Argentina $\left(36^{\circ} \mathrm{S}, 57^{\circ} \mathrm{W}\right.$, northern Buenos Aires province) (Lucherini et al. 2000) and two (one male and one female) in Los Alerces National Park $\left(43^{\circ} \mathrm{S}, 72^{\circ} \mathrm{W}\right.$, Chubut province; Lucherini et al. 2001, 2002). All these individuals were immobilized with an 
intramuscular injection of Zoletil® (tiletamine hydrochloride-zolazepam hydrochloride). Detailed information on cat trapping and handling is reported in Luengos Vidal et al. (2003) and Manfredi et al. (2006). Data from southern Brazil (ca. $31.5^{\circ} \mathrm{S}, 52.5^{\circ} \mathrm{W}$ ) were recorded from car-struck animals collected in four different areas: the Lagoon Patos/Mirim Complex, in the Costal Basin; the Southeast Ridge; the Rio Grande do Sul Central Depression; the Pampas at the borderline with Uruguay and Argentina. These data were gathered from two research projects: "Integrated Study of the Ecosystems in the Eucalyptus Forestation areas of the VCP Florestal S/A, State of Rio Grande do Sul", and "Wild Cats - Brazil". In addition, J. Pereira provided unpublished body masses of five adult cats (four males and one female) from Lihué Calel National Park $\left(37^{\circ} \mathrm{S}, 65^{\circ} \mathrm{W}\right.$, La Pampa province). We also added data collected from two car-struck individuals found in the proximities of Tornquist Park, and that were classified as being from the "southern Pampas".

These novel data were pooled with the unpublished information recorded in Torres del Paine National Park (southern Chile) by W. Johnson (Johnson \& Franklin 1991) and that reported by Ximénez $(1973,1975)$ for Uruguay (ca. $32.5^{\circ} \mathrm{S}, 55^{\circ} \mathrm{W}$ ) (Table 1 ).

Analysis of variance and Student t-tests were used to examine differences in body mass between areas and sexes. Since data distribution did not differ from normality, no transformation was needed.

\section{RESULTS}

When data were pooled across locality and sex, mean body mass of $O$. geoffroyi was $4.26 \mathrm{~kg}$ $(\mathrm{SD}=1.03 \mathrm{~kg}, \mathrm{n}=56$ individuals $)$. After data were separated by sex, males were heavier than females (one-tailed Student t-test, $\mathrm{t}_{55}=5.28, \mathrm{P}$ $=0.0001$ ), and body mass dimorphism was 1.34 on average, but ranged from 1.19 and 1.21 in Uruguay and southern Chile, respectively, to 1.76 in Campos del Tuyú (Table 1).

A two-factor ANOVA showed that body mass did vary with geograph location $\left(\mathrm{F}_{6,41}=\right.$ $8.07, \mathrm{P}=0.0001)$ and $\operatorname{sex}\left(\mathrm{F}_{1,41}=45.79, \mathrm{P}=\right.$ $0.0001)$. This analysis revealed a statistically significant interaction between location and sex $\left(\mathrm{F}_{6,41}=2.52, \mathrm{P}=0.036\right)$, meaning that body mass differed with sex but in some localities only. Our a-posteriori analysis (Tukey-Kramer test, $\mathrm{P}<0.05)$ confirmed that males were larger than females at Southern Brazil, Campos del Tuyú and Southern Pampas. Males tended to be heavier than females at Torres del Paine, Los Alerces, Lihué Calel and Uruguay (Table 1, Fig. 1), but not statistically significantly so. When the data from the five areas with the largest sample sizes (Torres del Paine, Lihué

TABLE 1

Mean adult Geoffroy's cat (Oncifelis geoffroyi) body mass $( \pm \mathrm{SD})$ geographical variation. Sample sizes in parenthesis

Variación geográfica de la masa corporal media $( \pm \mathrm{DE})$ de adultos de gatos monteses (Oncifelis geoffroyi). Tamaño de muestra en paréntesis

\begin{tabular}{llll}
\hline Study area & \multicolumn{2}{c}{ Body mass $(\mathrm{kg})$} & \multicolumn{1}{c}{$\begin{array}{c}\text { Sexual size dimorphism } \\
\text { (male size / female size) }\end{array}$} \\
\cline { 2 - 3 } Torres del Paine & $4.94 \pm 0.92(5)$ & $4.10 \pm 0.71(4)$ & 1.21 \\
Los Alerces & $4.5(1)$ & $3.25(1)$ & 1.38 \\
Lihué Calel & $4 \pm 0.61(4)$ & $2.8(1)$ & 1.43 \\
Southern Pampas & $5.18 \pm 0.68(4)$ & $3.33 \pm 0.48(4)$ & 1.48 \\
Campos del Tuyú & $7.4 \pm 0.57(2)$ & $4.2 \pm 0.17(3)$ & 1.76 \\
Uruguay & $3.7 *(5)$ & $3.1 *(5)$ & 1.19 \\
Southern Brazil & $4.6 \pm 0.61(14)$ & $3.48 \pm 0.51(9)$ & 1.32 \\
Mean & $4.78 \pm 0.99 *(32)$ & $3.57 \pm 0.61 *(24)$ & 1.34 \\
\hline
\end{tabular}

* For the calculation of average values we used the only two individual data (minimum and maximum) available for Uruguay. For the same reason, we report only the means for this study area 
Calel, southern Pampas, Campos del Tuyú and southern Brazil) are considered, male body mass did vary across locations (ANOVA, $\mathrm{F}_{4,24}$ $=9.34, \mathrm{P}=0.0014)$, but not female body mass (ANOVA, $\mathrm{F}_{3,16}=2.91, \mathrm{P}=0.67$; in this case Lihué Calel data were excluded, because they include only one female). Our a-posteriori analysis confirmed that males at Campos were heavier than at other localities. When all data are entered into the analysis, no correlation was found between body mass and latitude (Linear regression, $F_{1,54}=1.124, P=0.294$; Fig. 1).

\section{DISCUSSION}

Until now, $O$. geoffroyi was thought to weight $4.9 \mathrm{~kg}$ on average (Oliveira 1994) and individuals from the southern portion of the species' range were reported to be much larger than those from the north (Sunquist \& Sunquist 2002). Our results decrease the mean weight considerably, but increase its variation range. Even though the large size of $O$. geoffroyi specimens reported from the northern Buenos Aires province needs to be confirmed by additional data, our evidence clearly does not support that the largest individuals occur in the southernmost region of this cat's geographic distribution. This study demonstrate the existence of geographical variation in male body mass, but found no positive correlation with latitude, as might be expected from Bergmann's rule. Caution is needed, however, as Bergmann's rule might apply more to between than to within species variation in body mass (Blackburn et al. 1999).

Our data confirmed that sexual body mass dimorphism exists in this species, similarly to other felids (Kiltie 1988, Sunquist \& Sunquist 2002). Not only that, males were always larger than females at all localities examined, supporting a sexually selected scenario for sexlinked differences in body size. Since cubs in most felids are exclusively reared by the females, food supply is expected to determine how they are distributed, while spacing patterns of males would be affected by female distribution (Kleiman \& Eisenberg 1973, Sunquist \& Sunquist 2002). In this scenario, increased sexual dimorphism is predicted where stronger intra-sexual competition occurs.

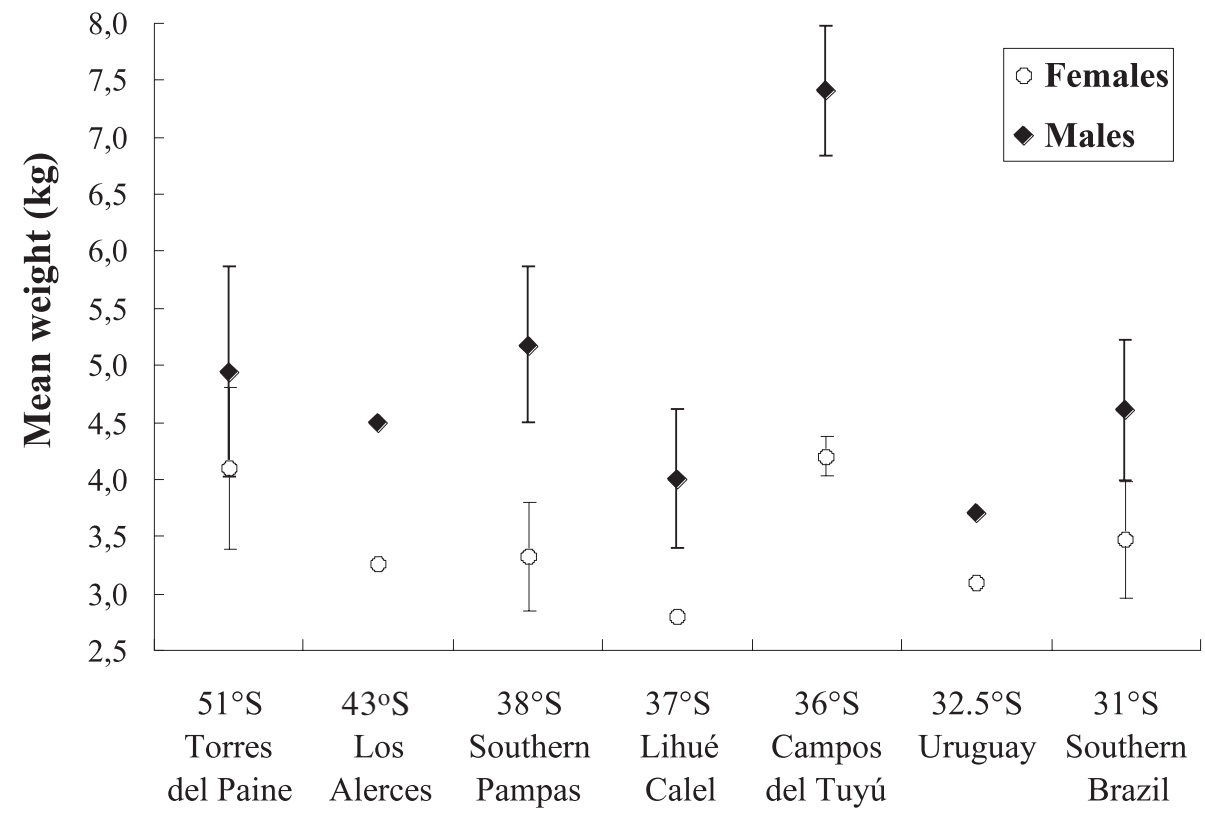

Fig. 1: Variation in the body mass $( \pm \mathrm{SD})$ of the Geoffroy's cat (Oncifelis geoffroyi) in relation to latitude.

Variaciones en la masa corporal ( \pm DE) del gato montés (Oncifelis geoffroyi) en relación a la latitud. 
When females can not be economically monopolized (e.g., when female ranges are wide), male home ranges would overlap extensively and male competition is expected to be high. Although ecological data are available from only two areas, they also seem to support that sexual selection explains sexual size dimorphism in Geoffroy's cat. In Campos del Tuyú, where male body size and sexual dimorphism were the greatest, home range overlap between adult males was extensive (Manfredi et al. 2006), while in Torres del Paine where male home range overlap is smaller, sexual size dimorphism is reduced (Johnson \& Franklin 1991).

Iriarte et al. (1990) found that body size in pumas (Puma concolor Linnaeus 1777) is directly correlated to prey size, but also affected by the presence of the jaguar (Panthera onca Linnaeus 1758). Intraguild competition affects carnivore populations (Palomares \& Caro 1999, Linnell \& Strand 2000), including those of South American small cats (Lucherini \& Luengos Vidal 2003), and may lead to character displacement (Strong et al. 1979, Dayan \& Simberloff 1996). Given that the mean weight of vertebrate prey in $O$. geoffroyi is considerably larger in Torres del Paine (Johnson \& Franklin 1991) than in the Pampas (Manfredi et al. 2004), while body mass shows the opposite, the effect of prey size on the body size of the Geoffroy's cat can be excluded. Unfortunately, the information on carnivore guild composition in the southern cone of South America is still limited, and more data are needed to understand the importance of intraguild competition in determining body mass and sexual dimorphism on this cat as well as that of other factors, such as contingent environmental factors, genetic drift and isolation (e.g., Rohlf \& Schnell 1971, Gould \& Johnston 1972).

\section{ACKNOWLEDGEMENTS}

We acknowledge J. Pereira and W.E. Johnson for kindly providing us the data on the body mass from the Geoffroy's cats they trapped in Lihué Calel National Park and Torres del Paine National Park, respectively, as well as to E. Eizirik and T. Trigo for those from five carstruck Geoffroy's cats they collected.W.E.
Johnson, V. Augusto and G. Bastazini and two anonymous referees revised the first draft of this Ms. and provided useful suggestions. We thank the members of GECM (especially M.J. Merino, D. Castillo, J. Baglioni, M. Ciuccio and S. Araujo), the staff of Fundación Vida Silvestre Argentina, Tornquist Provincial Park, Los Alerces National Park, and Patagonia office of the National Park Agency (APN), as well as all the volunteers who helped with trapping. M. Uhart (WCS), C. Marull, H. Ferreira, A. Balcarse and P. Beldoménico provided training on animal handling procedures. C.M. has been supported by postgraduate scholarships from UNS and Consejo Nacional de Investigaciones Científicas y Técnicas (CONICET), E.L. by postgraduate scholarships from Comisión de Investigaciones Científicas de la Provincia de Buenos Aires (CIC) and CONICET, and M.L. from postgraduate scholarships from CONICET and the IM40 grant of Agencia Nacional de Promoción Científica y Tecnológica (ANPCyT). This study was funded by Earthwatch Institute, Bosack and Kruger Foundation and Cat Action Treasury, Idea Wild, ISEC Canada, Wild About Cats, CIC, IM40 grant of ANPCyT, CONICET and SGCyT, UNS, grants 24/B087 and 24/B123. F Dias Mazim was supported by Projeto Gatos do Mato-Brasil: Estudo Integrado dos Ecossistemas nas Áreas de Florestamento de Eucalipto da VCP Florestal S/A, Rio Grande do Sul-Convênio Universidade Católica de Pelotas / Votorantim.

\section{LITERATURE CITED}

ASHTON KG, MC TRACY \& A DE QUEIROZ (2000) Is Bergmann's rule valid for mammals? American Naturalist 156: 390-415.

BLACKBURN TM, KJ GASTON \& N LODER (1999) Geographic gradients in body size: a clarification of Bergmann's rule. Diversity and Distribution 6: 165174

CABRERA A (1957) Catálogo de los mamíferos de América del Sur. Revista del Museo Argentino de Ciencias Naturales "Bernardino Rivadavia", Zoología 4: 1-370.

DAVIS SJM (1981) The effects of temperature change and domestication on the body size of Late Pleistocene to Holocene mammals of Israel. Paleobiology 7: 101-114.

DAYAN T \& D SIMBERLOFF (1996) Patterns of size separation in carnivore communities. In: Gittleman JL (ed) Carnivore behavior, ecology, and evolution, 
vol. 2: 243-266. Cornell University Press, Ithaca, New York, USA.

DAYAN T, D SIMBERLOFF, E TCHERNOV \& Y YOMTOV (1989 a) Inter- and intraspecific character displacement in mustelids. Ecology 70: 1526-1539.

DAYAN T, D SIMBERLOFF, E TCHERNOV \& Y YOMTOV (1989 b) Ecological character displacement in Saharo-Arabian Vulpes: outfoxing Bergmann's rule. Oikos 55: 263-272.

ERLINGE S (1979) Adaptive significance of sexual dimorphism in weasels. Oikos 33: 233-245.

ERLINGE S (1987) Why do European stoats Mustela erminea not follow Bergmann's rule? Holoarctic Ecology 10: 33-39.

GITTLEMAN JL (1995) Carnivore body size: ecological and taxonomic correlates. Oecologia 67: 540-554.

GOULD SL \& RF JOHNSTON (1972) Geographic variation. Annual Review of Ecology and Systematics 3: 457-498.

HEDRICK AV \& EJ TEMELES (1989) The evolution of sexual size dimorphism in animals: hypotheses and tests. Trends in Ecology and Evolution 4: 136-138.

IRIARTE JA, WL FRANKLIN, WE JOHNSON \& KE REDFORD (1990) Biogeographic variation of food habits and body size of the American puma. Oecologia 85: 185-190.

JOHNSON WE \& WL FRANKLIN (1991) Feeding and spatial ecology of Felis geoffroyi in southern Patagonia. Journal of Mammalogy 72: 815-820.

KILTIE RA (1988) Intraspecific size regularities in tropic felid assemblages. Oecologia 76: 97-105.

KLEIMAN D \& J EISENBERG (1973) Comparison of canid and felid social systems from an evolutionary perspective. Animal Behaviour 21: 637-659.

KLEIN RG (1986) Carnivore size and Quaternary climatic change in southern Africa. Quaternary Research 26: 153-170.

LINNELL \& DC STRAND (2000) Interference interactions, co-existence and conservation of mamalian carnivores. Diversity Distributions 6: 169-176.

LUCHERINI M \& E LUENGOS VIDAL (2003a) Intraguild competition as a potential factor affecting the conservation of two endangered cats in Argentina. Endangered Species Updates 2: 211-220.

LUCHERINI M, L SOLER, C MANFREDI, A DESBIEZ \& C MARULL (2000) The Geoffroy's cat in the Pampas grasslands. Cat News 33: 22-24.

LUCHERINI $M, E$ LUENGOS VIDAL \& $P$ BELDOMENICO (2001) First record of sympatry of guigna and Geoffroy's cat. Cat News 35: 20-21.

LUCHERINI M, D CASTILLO \& M CIUCCIO (2002) Guigna and Geoffroy's cat in Patagonian Mountain forest. Cat News 36: 23-24.

LUCHERINI M, L SOLER \& E LUENGOS VIDAL (2004) A preliminary revision of knowledge status of felids in Argentina. Journal of Neotropical Mammalogy 11: 7-17.

LUENGOS VIDAL E, M LUCHERINI \& E CASANAVE (2003a) An evaluation of three live-traps for capturing Pampas foxes. Canid News 6: 1-10.

MANFREDI C, M LUCHERINI, A CANEPUCCIA \& E CASANAVE (2004) Geographical variation in the diet of Geoffroy's cat (Oncifelis geoffroyi) in Pampas grassland of Argentina. Journal of Mammalogy 85: 1111-1115.
MANFREDI C, L SOLER, M LUCHERINI \& E CASANAVE (2006) Home range and habitat use by Geoffroy's cat (Oncifelis geoffroyi) in a wet grassland in Argentina. Journal of Zoology (London) 268: 381-387

MAYR E (1956) Geographical character gradients and climatic adaptations. Evolution 10:105-108.

MCNAB BK (1971) On the ecological significance of Bergmann's rule. Ecology 52: 845-854.

MOORS PJ (1980) Sexual dimorphism in the body size of mustelids (Carnivora): the roles of food habits and breeding systems. Oikos 34: 147-158.

NOWELL K (2002a) Revision of the Felidae Red List of Threatened Species. Cat News 37: 4-6.

NOWELL K (2002b) The Cat Specialist Group digital library as a measure of cat conservation effort. Cat News 37: 23-24.

NOWELL K \& P JACKSON (1996) Wild cats. Status Survey and Conservation Action Plan. IUCN/SSC Cat Specialist Group, Gland, Switzerland. xxiv +382 pp.

OLIVEIRA TG (1994) Neotropical cats: ecology and conservation. Universidade Federal do Maranhãnao Press, San Luis, Brazil. xxiv + 220 pp.

OLROG CA \& MM LUCERO (1981) Guía de los mamíferos argentinos. Fundación Miguel Lillo, Tucumán, Argentina. viii +151 pp.

PALOMARES F \& TM CARO (1999) Interespecific killing among mamalian carnivores. American Naturalist 153: 492-508.

POWELL RA \& CA KING (1997) Variation in body size, sexual dimorphism and age-specific survival in stoats, Mustela erminea (Mammalia: Carnivora), with fluctuating food supplies. Biological Journal of the Linnean Society 62: 165-194.

RALLS K (1976) Mammals in which females are larger than males. Quarterly Review of Biology 51: 245-275.

REDFORD K \& JF EISEMBERG (1992) Mammals of the Neotropics: the southern cone. University of Chicago Press, Chicago, Illinois, USA. ix +430 pp.

ROHLF FJ \& GD SCHNELL (1971) An investigation of the isolation-by-distance model. American Naturalist 105: 295-324.

ROSENZWEIG ML (1968) The strategy of body size in mammalian carnivores. American Midland Naturalist 80: 299-315.

STRONG DR, LA SZYSKA \& D SIMBERLOFF (1979) Tests of community-wide character displacement against null hypotheses. Evolution 33: 897-913.

SUNQUIST M \& F SUNQUIST (2002) Wild cats of the world. Chicago University Press, Chicago, Illinois, USA. $\mathrm{x}+452 \mathrm{pp}$.

THOM MD, LA HARRINGTON \& DW MACDONALD (2004) Why are American mink sexually dimorphic? A role for niche separation. Oikos 105: 525-535.

VAN VALKENBURGH B \& RK WAYNE (1994) Shape divergence associated with size convergence in sympatric east African jackals. Ecology 75: 1567 1581.

XIMÉNEZ A (1973) Contribución al conocimiento de Felis geoffroyi D'Orbigny \& Gervais, 1844 y sus formas geográficas (Mammalia, Felidae). Papéis Avulsos Zoologie 27: 31-43.

XIMÉNEZ A (1975) Felis geoffroyi. American Society of Mammalogists, Mammalian Species 54: 1-4. 